\title{
ZATRZYMAĆ CZY POZWOLIĆ? NIEOCZYWISTE SKUTKI SUBURBANIZACJI. STUDIUM PODOLSZTYŃSKICH GMIN WIEJSKICH
}

\author{
TO STOP OR TO PERMIT? \\ UNOBVIOUS EFFECTS OF SUBURBANIZATION. \\ STUDIES OF THE RURAL COMMUNES \\ IN THE VICINITY OF OLSZTYN
}

Nr DOI: $10.25167 / \mathrm{sm} 2017.026 .01 \quad$ s. 9-23

\begin{abstract}
ABSTRAKT: Suburbanizacja to proces wzbudzający wiele kontrowersji, a autorzy opracowań często podkreślają jej negatywne konsekwencje. Celem niniejszego opracowania jest ukazanie jej nieoczywistych skutków przy uwzględnieniu badań lokalnych. Posłużono się m.in. metodą opisową, uzupełnioną obliczeniami, a także metodą estymacji jądrowej. Jak wynika z obserwacji, zabudowa podmiejska może być skoncentrowana przy istniejących urządzeniach infrastrukturalnych, a realizacja nowych inwestycji to proces wieloletni, nie powodujący zatem konieczności ponoszenia nakładów w krótkim czasie. Pozytywnym następstwem suburbanizacji może być natomiast wzrost wpływów budżetowych w gminach podmiejskich oraz przesunięcie ruchu na drogi o większej przepustowości. Ponadto korzyści odnoszą sami mieszkańcy w wyniku poprawy jakości przestrzeni mieszkalnej.
\end{abstract}

SŁOWA KLUCZOWE: suburbanizacja, gminy wiejskie, problemy lokalne

\begin{abstract}
Suburbanization means a controversial process and many authors often underline its negative consequences. This paper is aimed at presenting its unobvious effects on the basis of local studies. The relevant analyses were conducted with the descriptive method, complemented with calculations and nuclear estimation. It was observed that suburban residential development can be concentrated along existing infrastructural facilities and the new investments are a long-term process, thus new settlements do not mean additional expenditures in a short term. However, a positive consequence of suburbanization is, among others, increasing financial incomes in the commune's budget or shifting the traffic to roads with better capacity. There are also benefits for the inhabitants, such as improvement of the living space.
\end{abstract}

KEY WORDS: suburbanization, urban sprawl, rural communes

* Uniwersytet Warmińsko-Mazurski, Wydział Nauk Ekonomicznych, Katedra Polityki Gospodarczej i Regionalnej, e-mail: alina.zrobek@uwm.edu.pl.

** Uniwersytet Warmińsko-Mazurski, Wydział Geodezji, Inżynierii Przestrzennej i Budownictwa, Katedra Zasobów Nieruchomości, e-mail: ada.wolny@uwm.edu.pl. 


\section{Wprowadzenie}

Suburbanizacja towarzyszy rozwojowi dużych miast, a termin suburbium był już używany do określenia zabudowań zlokalizowanych poza murami starożytnego Rzymu (Bruegmann 2005). Współcześnie suburbanizacja wciąż jest procesem powszechnym oraz w znacznej mierze nieuniknionym (Bagiński 2011). Przebieg procesu, jego przyczyny i konsekwencje stanowią obiekt badań wielu naukowców, zarówno krajowych (m.in. Bagiński 2011, Heffner 2011, Problem suburbanizacji 2005, Zborowski, Raźniak 2013), jak i zagranicznych (m.in. Brueckner 2001, Brueckner, Largey 2008, Bruegmann 2005, Burchfield et al. 2006, Cheshire, Sheppard 2002, Glaeser, Kahn 2003, Irwin, Bockstael 2007, Nechyba, Walsh 2004, Wu 2006). W wyniku rozważań sformułowano wiele wniosków, w tym również obaw, oraz zalecano powstrzymanie suburbanizacji. Opinie negujące to zjawisko wygłaszane są na całym świecie (m.in. Bento, Franco, Kaffine 2011, Charmes 2009, Coisnon, Oueslati, Salanie 2014, Fisher 1942, Kajdanek 2012, Kowalewski et al. 2014, Nelson et al. 2004, Pieniążek, Rogalińska 2015, Plantinga, Bernell 2007, Richardson, Gordon 2001). Liczny zbiór niekorzyści przytoczyli m.in. Jan K. Brueckner i Robert W. Helsey (2011). Argumentowano na przykład, iż miasta brutalnie wdzierają się na ziemie rolne, prowadząc do utraty korzyści wynikających z otwartej przestrzeni oraz wyczerpywania się rzadkich zasobów. Ponadto podkreślano, iż ekspansja miast na tereny podmiejskie powoduje nadmierną kongestię i zanieczyszczenie powietrza. Dodatkowo wykraczanie funkcji miejskich poza granice administracyjne powiązano z niedostateczną rewitalizacją centrów miast, prowadzącą do degradacji obszarów śródmiejskich (Mieszkowski, Mills 1993). Krytyczne uwagi co do procesu suburbanizacji są upowszechniane w opracowaniach naukowych i raportach (np. Paszkowski 2014), głoszone na seminariach ${ }^{1}$ oraz opisywane w prasie popularnej lub umieszczane na specjalistycznych portalach internetowych (np. Instytutu Obywatelskego). Polscy naukowcy zwracają szczególną uwagę na aspekty kosztowe wynikające m.in. z: potrzeby rozbudowy infrastruktury dla rozproszonej podmiejskiej zabudowy, wydłużonych dojazdów do miasta własnym samochodem oraz tworzącego się zatłoczenia na drogach. Jednocześnie proces suburbanizacji ma również swoich zwolenników i obrońców, według których podkreślanie negatywnych aspektów procesu z uprzedzeniami oraz stronniczością wynika z nadmiernego gloryfikowania atutów życia w mieście (np. Bruegmann 2006).

Bezkrytyczne opowiadanie się za zaletami lub wadami suburbanizacji oraz jednokierunkowa polityka przestrzenna wydają się jednak nieodpowiednie przy tak złożonym zagadnieniu. Niejednoznaczność konsekwencji postępującego zjawiska zachęciła autorki niniejszego artykułu do podjęcia próby porównania często spotykanych argumentów przeciwko suburbanizacji z rzeczywistymi przypadkami zaobserwowanymi na obszarze gmin położonych w strefie oddziaływania miasta Olsztyna, stolicy województwa warmińsko-mazurskiego.

110 października 2014 r. w olsztyńskim Parku Naukowo-Technologicznym odbyła się konferencja pt. „Powrót do miasta”. 
Z zasobnej puli uwag krytycznych wyodrębniono te związane z infrastrukturą i trans portem. Wybór uzasadniono faktem, iż nastanie epoki motoryzacji i towarzyszące jej obniżenie kosztów transportu były elementarnym katalizatorem rozlewania się miast w XX w. (Glaeser, Kohlhase 2003). Ponadto elastyczność dochodowa popytu na domy pod miastem jest większa od elastyczności cenowej dojazdów do miasta (Nechyba, Walsch 2004). W efekcie wraz ze wzrostem dochodów (Margo 1992) i zdolności kredytowej oraz rosnącą liczbą samochodów (szczególnie zauważalną po wejściu Polski do UE) wielu Polaków przeprowadziło się na podmiejską wieś i dojeżdża codziennie do miasta ${ }^{2}$. Skala i powszechność zjawiska uzasadniają podjęcie opisanego problemu badawczego.

\section{Konsekwencje suburbanizacji w świetle studium przypadku wybranych gmin}

W niniejszym artykule podjęto próbę porównania popularnych uwag krytycznych wobec suburbanizacji z obserwacjami poczynionymi w miejscowościach położonych w gminach bezpośrednio sąsiadujących z Olsztynem. Koncentrację zabudowy mieszkaniowej zbadano przy zastosowaniu jednej z metod geostatystyczych - estymacji jądrowej, która określa gęstość obiektów w zadanym obszarze. Metoda oszacowania rozkładu gęstości dobiera powierzchnię ciągłą do zbioru danych opisujących obiekty dyskretne. Zbiór danych może zawierać wartości zmiennej ciągłej zmierzone w punktach pomiarowych lub atrybuty opisujące obiekty dyskretne. W przypadku obiektów dyskretnych przestrzeń między nimi jest pusta (Longley et al. 2006). Metoda ta jest najczęściej wykorzystywana w analizie danych punktowych. Każda funkcja gęstości ma towarzyszący jej parametr długości (promień), który steruje jej kształtem, czyli stopniem spłaszczenia. W oszacowaniu gęstości zjawiska każdy obiekt punktowy zostaje zastąpiony wartością obliczoną według funkcji gęstości prawdopodobieństwa, a następnie dodawane są wartości funkcji w celu zyskania powierzchni zagregowanej lub ciągłego pola gęstości (Longley et al. 2006). Zmieniając szerokość podstawy krzywej, można dopasować jej kształt i obliczyć powierzchnię gęstości o różnym stopniu wygładzenia. Dla zmiennej losowej o charakterze jednowymiarowym wymagana liczność próby to przedział 20-50, przy odpowiednim zwiększeniu, biorąc pod uwagę wzrost wymiaru zmiennej. Najpopularniejsze postacie funkcji jądrowych usystematyzował Cellmer (2012 za Piotrem Kulczyckim), wśród których możemy wyróżnić estymatory: równomierny, trójkątny, normalny, Epanechnikova i czwartego stopnia - w zależności od rodzaju jądra funkcji. W badaniach przeprowadzonych na potrzeby artykułu przyjęto estymator jądrowy czwartego stopnia (quatric kernel).

\footnotetext{
2 Np. w 2015 r. z Warszawy, Poznania i Krakowa na wieś wymeldowało się odpowiednio 5644, 4711 i 3605 osób, a z Lublina i Olsztyna - odpowiednio 2135 i 1084 osoby. Jednocześnie w sześciu podolsztyńskich gminach zameldowało się 1435 osób, z czego 80\% mieszkało wcześniej w miastach (dane GUS).
} 
Wyniki analizy przedstawiono w relacji do istniejącego układu komunikacyjnego, z wyróżnieniem głównych dróg w gminie. Dane pozyskano z serwisów ogólnodostępnych (głównie OpenStreetMap), a następnie uzupełniono informacjami pochodzącymi z lokalnego systemu informacji przestrzennej. Selekcję, przetworzenie oraz prezentację wyników wykonano w oprogramowaniu środowiska GIS (QGIS). Dalsze rozważania uporządkowano w nawiązaniu do czterech głównych zarzutów formułowanych wobec procesu suburbanizacji (oznaczonych kolejnymi literami alfabetu).

\section{Rozbudowa infrastruktury drogowej dla zabudowy podmiejskiej jako nadmierne obciążenie finansowe gmin}

Wytyczenie w miejscowym planie zagospodarowania przestrzennego (MPZP) obszaru pod zabudowę jest jednocześnie swoistą deklaracją finansową gminy, ponieważ zobowiązuje się ona przez to do zapewnienia infrastruktury, m.in. dróg dojazdowych. W praktyce są to jednak zobowiązania o charakterze potencjalnym, ponieważ niewiele gmin podejmuje się szybkiej realizacji inwestycji drogowych na terenach zarówno wyznaczonych pod zabudowę, jak i faktycznie zabudowanych. Przykładem może być warmińsko-mazurska wieś Naglady, położona $15 \mathrm{~km}$ od centrum Olsztyna. Nowe osiedle mieszkaniowe zlokalizowano na działkach sprzedawanych od 2010 r. przez gminę Gietrzwałd. Do roku 2016 gmina nie rozpoczęła inwestycji związanych z nawierzchnią dróg pomimo rozwijającej się zabudowy obszaru (rysunek 1).

Szczegółowej analizie poddano także przypadek z gminy Dywity. W miejscowości Różnowo część terenów, na mocy uchwały nr XXXII/269/09 Rady Gminy w Dywitach,

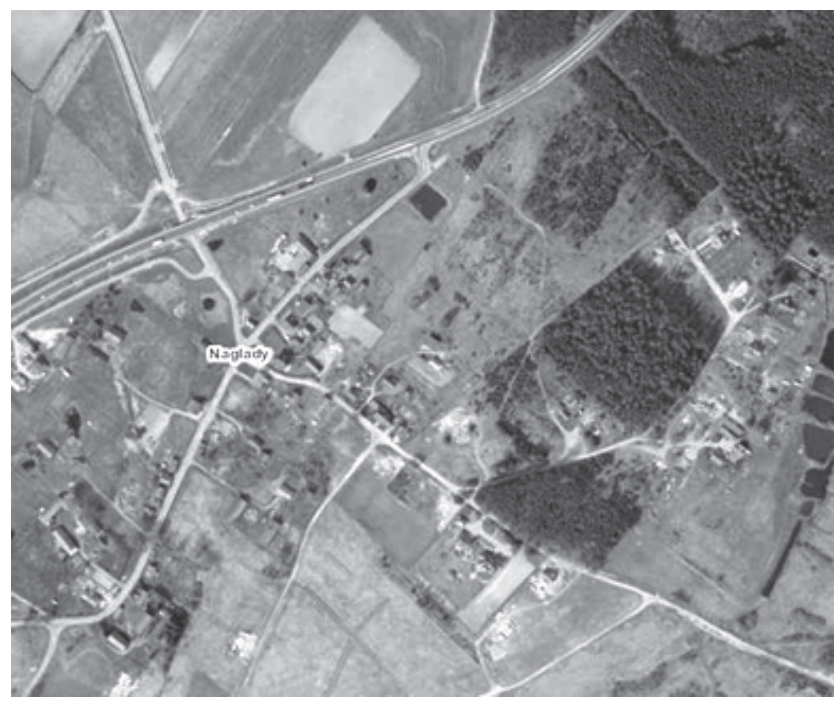

Rys. 1. Stan nawierzchni dróg w podmiejskiej wsi Naglady

Źródło: Google Maps (dostęp 6 września 2016). 
została przeznaczona głównie pod zabudowę mieszkaniową. Dla obszaru objętego MPZP zaprojektowano nowy układ komunikacyjny składający się z dróg gminnych oraz wewnętrznych dróg dojazdowych (rysunek 2).

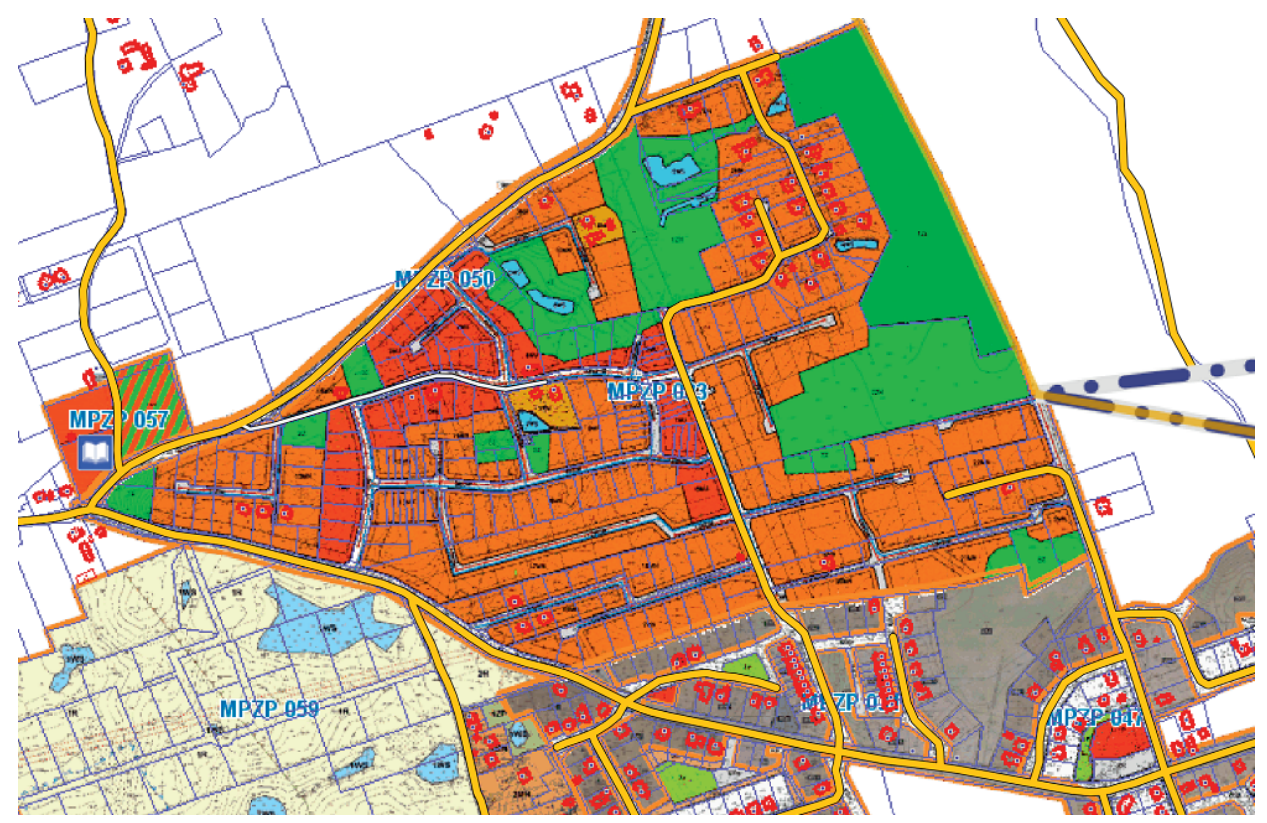

Rys. 2. Układ komunikacyjny w podmiejskiej wsi Różnowo na terenie objętym MPZP

Źródło: opracowanie własne na podstawie http://dywity.e-mapa.net (dostęp 25 sierpnia 2016).

W 2010 r. dokonano podziału nieruchomości na obszarze objętym przedmiotowym planem, w wyniku czego wyodrębniono blisko 30 działek ewidencyjnych współtworzących nowy układ komunikacyjny (rysunek 3 ).

$\mathrm{Z}$ danych pozyskanych z systemu informacji przestrzennej prowadzonego dla Urzędu Gminy Dywity wynika, iż poza podziałem geodezyjnym terenu nie podjęto dalszych działań w zakresie rozwoju lokalnego układu komunikacyjnego. Należy jednak wspomnieć, że gmina część obowiązków związanych z rozbudową infrastruktury przekazała właścicielom nieruchomości - działki powstałe w wyniku podziału nieruchomości, oznaczone jako tereny lokalnych i dojazdowych dróg publicznych (będące przedmiotem własności gminy), stanowią jedynie $41 \%$ tego terenu. Podstawą nowego układu komunikacyjnego na obszarze opracowania planu są zatem wydzielone drogi wewnętrzne, za których urządzenie i późniejsze utrzymanie odpowiedzialni są właściciele nieruchomości (zatem gmina nie ponosi z tego tytułu dodatkowych kosztów). Z tego względu rozwój układu komunikacyjnego można zaobserwować jedynie w miejscach występowania już wzniesionej zabudowy mieszkaniowej (rysunki 2 i 3). Do 2016 r. powstały jedynie fragmenty dróg w północnej części obszaru, dla którego został opracowany miejscowy plan (rysunek 4). 


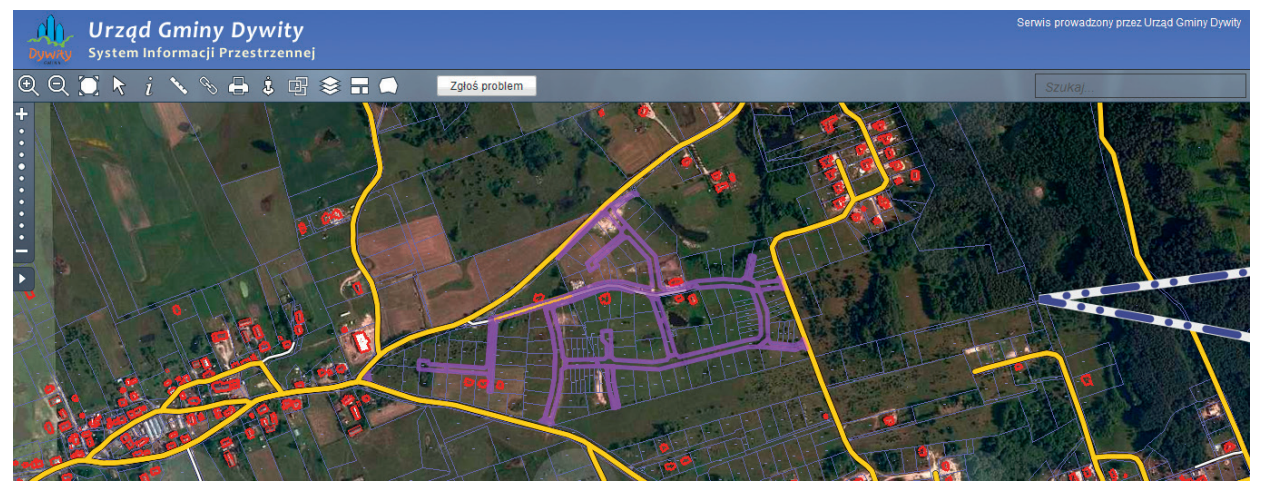

Rys. 3. Przestrzenne skutki podziału terenów w podmiejskiej wsi Różnowo (układ komunikacyjny) Źródło: jak w rysunku 2.

Powyższe obserwacje potwierdzają, iż obciążające budżet gminy wydatki związane z rozbudową układów komunikacyjnych mają charakter potencjalny. Dodatkowo przeanalizowano sprawozdania z realizacji budżetu wspomnianej już gminy Dywity, która jest jedną z dwóch podolsztyńskich gmin cieszących się dynamicznym wzrostem liczby ludności. Na przestrzeni 10 lat nie zauważono bezpośredniej zależności między przyrostem liczby mieszkańców a wydatkami na drogi gminne (współczynnik korelacji 0,18) oraz między przyrostem liczby mieszkańców a wydatkami na inwestycje towarzyszące drogom, np. chodniki czy oświetlenie (współczynnik korelacji 0,12) (rysunek 5).

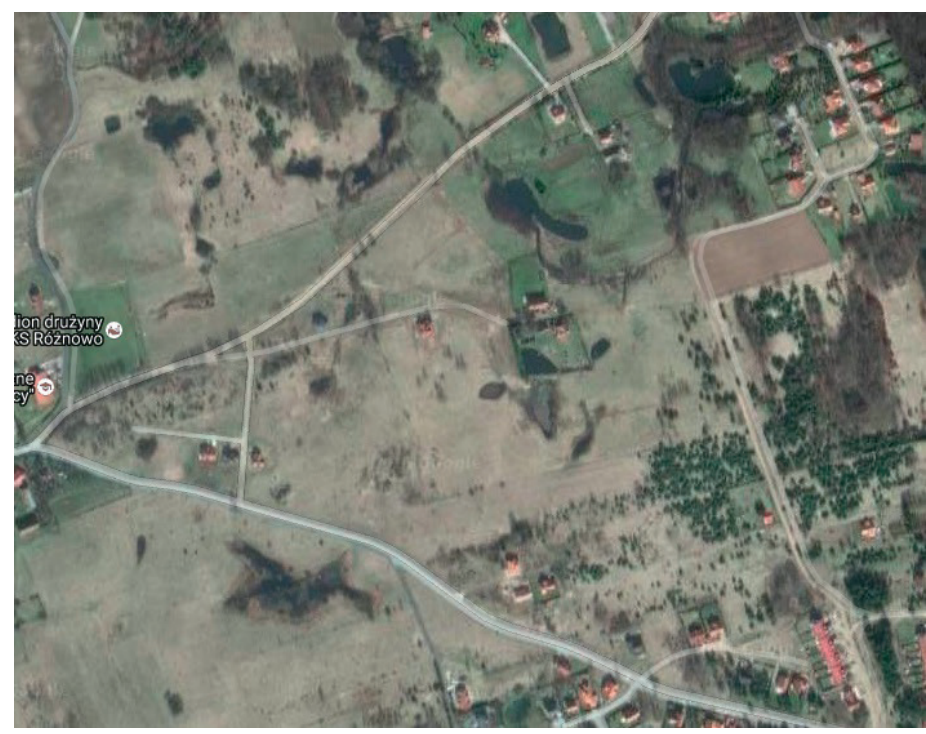

Rys. 4. Stan nawierzchni dróg w podmiejskiej wsi Różnowo

Źródło: Google Maps (dostęp 23 września 2016). 


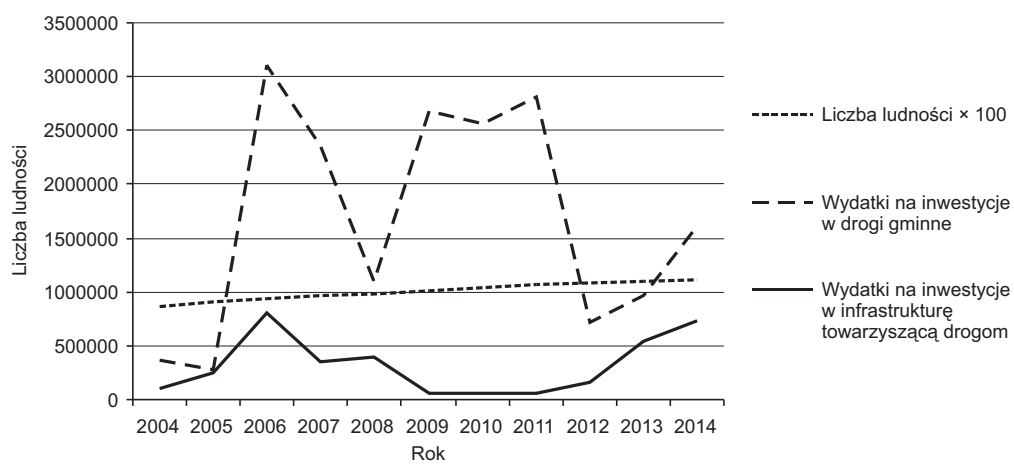

Rys. 5. Dynamika liczby ludności, wydatków na inwestycje w drogi gminne i infrastrukturę towarzyszącą drogom w podmiejskiej gminie Dywity. W celu poprawy czytelności wykresu liczbę osób pomnożono razy 100

Źródło: opracowanie własne na podstawie sprawozdań z realizacji budżetu gminy Dywity za lata 2004-2014.

Liczba ludności w latach 2004-2014 przyrastała w sposób liniowy, natomiast inwestycje odbywały się w sposób skokowy, w zależności od długoletnich planów inwestycyjnych gminy oraz uzyskanych środków zewnętrznych. Realizacja inwestycji przynoszących korzyść wyłącznie nowym mieszkańcom wymagałaby przychylności Rady Gminy, a dopiero odpowiednio duża liczba nowych mieszkańców skupionych na małym obszarze umożliwia uzyskanie większości głosów (Źróbek-Różańska, Zadworny 2016). Z kolei duża skala zaludnienia uzasadnia ekonomicznie (malejący koszt jednostkowy) oraz społecznie (duża liczba beneficjentów) realizację kosztownych inwestycji ${ }^{3}$. Ponadto warto podkreślić, iż nowi mieszkańcy generują wpływy do budżetu gminy, z tytułu zarówno podatku od nieruchomości, jak i części podatku dochodowego, mogą zatem oczekiwać inwestycji realizowanych na swoją korzyść. Wpływy generowane przez nowych mieszkańców są znaczące, ponieważ podatek od nieruchomości w Polsce wciąż zależy od powierzchni użytkowej (średnia powierzchnia nowo budowanych domów wynosi 120-150 $\mathrm{m}^{2}$ ), a dochody osób budujących domy zwykle muszą gwarantować zdolność kredytową.

\section{Suburbanizacja jako chaotyczna i rozproszona zabudowa, podnosząca koszty rozbudowy infrastruktury technicznej}

Brak ładu przestrzennego i rozproszenie zabudowy zmniejszają efektywność inwestycji infrastrukturalnych. W przypadku podolsztyńskich terenów wiejskich zaobserwowano korzystny trend, ponieważ zabudowa mieszkaniowa jest bardziej skoncentrowana niż rozproszona. W przykładowej gminie Dywity zaobserwowano wyraźną

3 Wyjątkowo zdarzają się również sytuacje, gdy nowi mieszkańcy są wręcz przeciwni budowie dróg utwardzonych i montażu oświetlenia ulic, które, ich zdaniem, zniszczy unikalny charakter mieszkania na wsi. Taka sytuacja wystąpiła we wsi Kaborno w podmiejskiej gminie Purda. 
koncentrację zabudowy w południowej i południowo-wschodniej jej części. Gmina ta graniczy z Olsztynem od północy, a większość istniejącej i nowo powstającej zabudowy koncentruje się bezpośrednio przy granicy z miastem lub wzdłuż drogi krajowej nr 51 przecinającej gminę na osi północ-południe (rysunek 6)4.

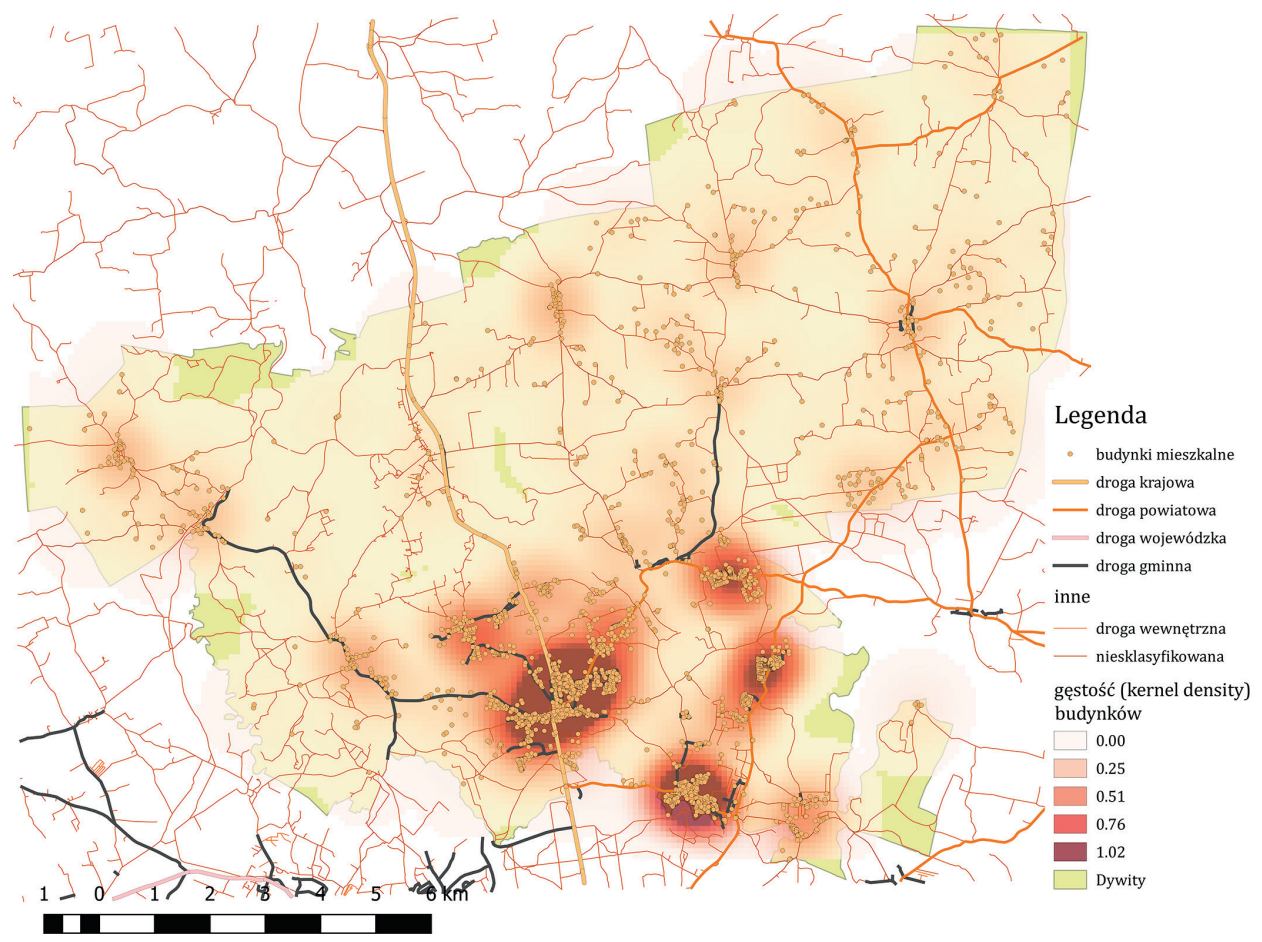

Rys. 6. Koncentracja zabudowy mieszkaniowej na terenie podmiejskiej gminy Dywity

Źródło: opracowanie własne.

Obszary o mniejszej koncentracji budynków mieszkalnych w północnej części gminy to dawno powstałe osady o typowo wiejskim, tradycyjnie rolniczym charakterze. W przeciwieństwie do południowej części gminy nie ulegają one istotnym przemianom na skutek suburbanizacji. W badaniach określających stan rynku nieruchomości i preferencje nabywców nieruchomości gruntowych w przedmiotowej gminie (Wolny 2016) działki w północnej części gminy są przedmiotem obrotu znacznie rzadziej niż te zlokalizowane na południu i południowym wschodzie. Powyższy stan w znacznej mierze nie wynika ze starannego zarządzania przestrzenią $w$ gminach, w których pokrycie planami miejscowymi wynosi od 2 do $15 \%$ (dane GUS), lecz z preferencji nabywców nieruchomości.

\footnotetext{
4 Koncentrację budynków zbadano z wykorzystaniem estymacji jądrowej (jądro typu quatric)
} 
Jak wynika z badań własnych (Źróbek-Różańska, Zysk, Źróbek-Sokolnik 2016) oraz z badań innych naukowców (Źróbek et al. 2015, Trojanek 2009), jedną z najważniejszych cech wybieranej lokalizacji jest poczucie bezpieczeństwa, dla którego wskaźnik ważności wyniósł odpowiednio: 0,8; 0,8 oraz 0,75. Na poczucie bezpieczeństwa składa się w dużej mierze bliskość innych osób (sąsiadów), stąd też często spotykana skłonność inwestorów do budowy domów mieszkalnych blisko istniejących osiedli. W praktyce rozwój osiedli mieszkaniowych nie oznacza jednakże intensywnych inwestycji w budowę sieci kanalizacyjnych czy gazowych, np. na terenie gminy Dywity kilometraż sieci kanalizacyjnej jest wciąż stosunkowo niewielki. Na terenie większości miejscowości brakuje zorganizowanego systemu oczyszczania ścieków, praktycznie cała zabudowa mieszkaniowa ogrzewana jest w sposób indywidualny, a dostęp do sieci gazowej mają tylko nieliczne miejscowości położone najbliżej Olsztyna (Plan Rozwoju Lokalnego... 2004).

\section{Rozpraszanie podmiejskiej zabudowy i oddalenie od miasta jako czynnik wydłużający dojazdy do pracy i zwiększający ich koszt oraz skazujący mieszkańców suburbiów na transport indywidualny}

W przypadku gmin podolsztyńskich zaobserwowano, iż zabudowania lokalizowane są najczęściej przy istniejących ciągach komunikacyjnych oraz w miejscowościach dobrze skomunikowanych z miastem przy wykorzystaniu komunikacji publicznej. Wynika to także w znacznym stopniu z indywidualnych wyborów inwestorów. Z badań nad preferencjami nabywców nieruchomości podmiejskich wynika bowiem, iż przypisują oni wysoką wagę dogodnemu dojazdowi do miasta - wskaźnik ważności dla tej cechy lokalizacji wyniósł: 0,8 (Źróbek-Różańska, Zysk, Źróbek-Sokolnik 2016); 0,8 (Trojanek 2009) i 0,7 (Źróbek et al. 2015). Ponadto napotykane w literaturze i mediach sformułowanie „skazani na transport indywidualny” wydaje się nieodpowiednie w czasach, w których przedkładanie podróży własnym samochodem wydaje się charakterystyczne dla mieszkańców zarówno podmiejskich wsi, jak i samych miast, i wynika w znacznej mierze z wygody, a nie konieczności. Potwierdzają to dane obrazujące sytuację komunikacji publicznej w polskich miastach. Większość pasażerów komunikacji publicznej to osoby młode i uczące się ${ }^{5}$ lub starsze (Radziewicz et al. 2013), korzystające z przejazdów ulgowych. W Olsztynie osoby w wieku 25-69 lat to w większości podróżujący własnym samochodem osobowym (Plan zrównoważonego rozwoju... 2012). Można zatem wyciągnąć wniosek, iż potencjalni mieszkańcy podmiejskich wsi, osoby w wieku 25-40 lat (Źróbek-Różańska, Zysk 2015), to osoby, które preferują przemieszczanie się własnym samochodem niezależnie od dostępności środków transportu publicznego. Podobnie jest także w innych miastach, np. w Białymstoku komunikacja miejska jest wykorzystywana przez mieszkańców w zaledwie 30\% jako główny środek transportu,

\footnotetext{
5 Choć badania przeprowadzone w 2016 r. wśród studentów Uniwersytetu Warmińsko-Mazurskiego w Olsztynie wykazały, że aktualnie już 35\% osób dojeżdża na uczelnię własnym samochodem osobowym, a wiodącą przyczyną jest wygoda.
} 
natomiast 70\% ludności przejazdy realizuje za pomocą indywidualnych środków przemieszczeń (Wappa, Halicka 2011). Można założyć, iż preferencje te zostaną utrzymane po przeprowadzce pod miasto.

Specyficzną grupę stanowią natomiast uczniowie szkół ponadgimnazjalnych, zarówno „napływowi”, jak i „rdzenni”, którzy muszą dojeżdżać do miasta w związku z edukacją, a nie posiadają samochodów lub/i uprawnień do kierowania nimi. W tym przypadku w najbardziej atrakcyjnych mieszkaniowo podmiejskich miejscowościach popyt jest zaspokajany przez wydłużone linie autobusowe lub usługi oferowane przez prywatnych przewoźników ${ }^{6}$. Na terenie gmin podmiejskich funkcjonuje obecnie sześć linii zapewniających dojazd do miasta. Gmina Dywity należy do najlepiej skomunikowanych z miastem także ze względu na rozmieszczenie przystanków autobusowych, które obejmują swym zasięgiem (promień 1000 m) obszary o największej koncentracji zabudowy w gminie (rysunek 7).

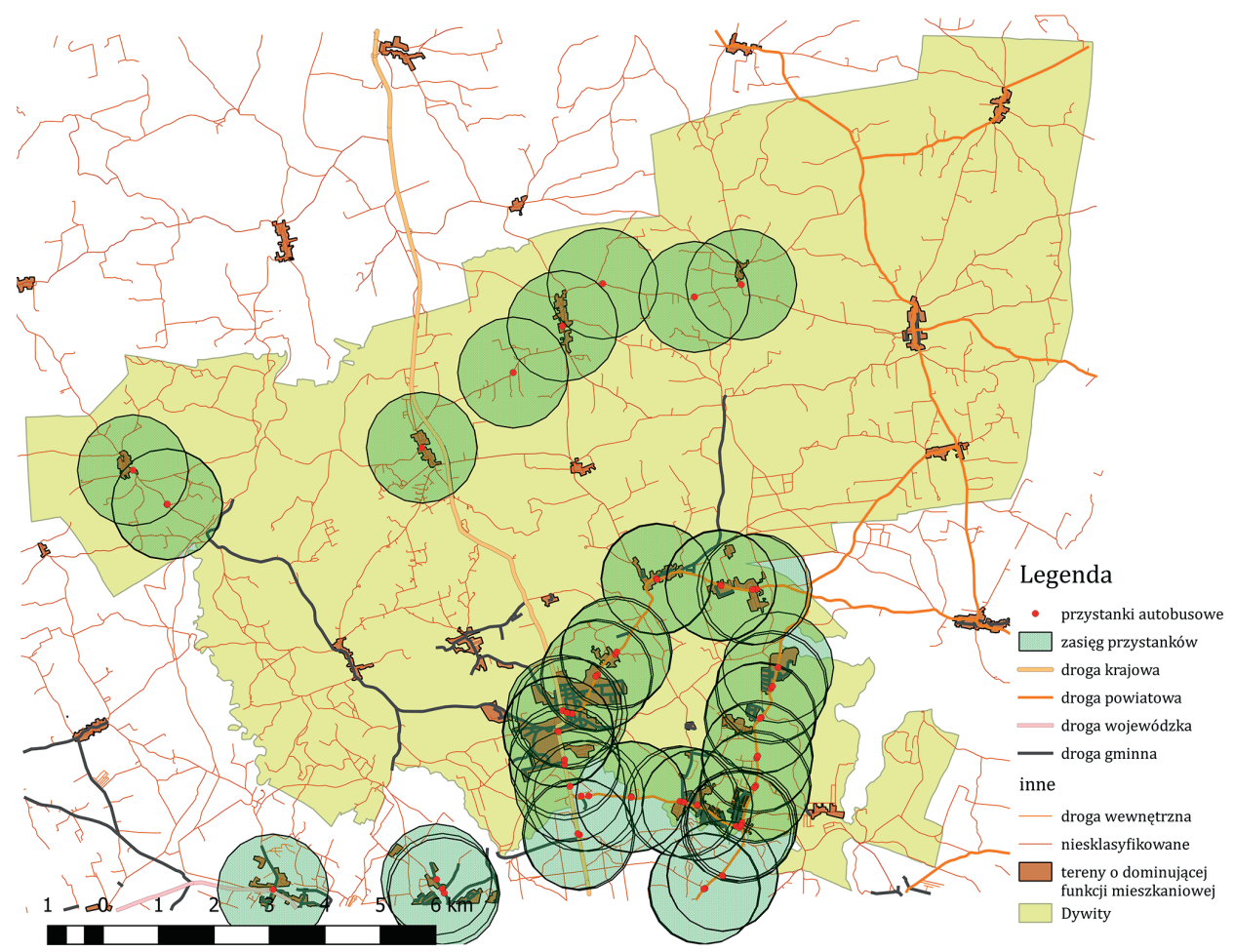

Rys. 7. Rozmieszczenie i zasięg przystanków autobusowych na terenie podmiejskiej gminy Dywity Źródło: jak w rysunku 6.

6 Opłata za przejazd środkami transportu publicznego (niezależnie od długości trasy) w Olsztynie wynosi 2,90 zł; u prywatnego przewoźnika za przejazd z gminy podmiejskiej Stawiguda do centrum Olsztyna płaci się 3,00 zł. 
Planowane są inwestycje w tym zakresie. Gminy podolsztyńskie pozyskały środki z UE na rozwój połączeń z miastem centralnym. Gmina Dywity i Stawiguda planują stworzyć własną komunikację gminną, która połączy kilkanaście podmiejskich miejscowości z Olsztynem (Szydłowski 2016).

\section{Suburbanizacja jako czynnik kreujący kongestię}

Zatłoczenie w układzie komunikacyjnym jest zjawiskiem niekorzystnym i dotyczy przede wszystkim ośrodków miejskich. Wraz z dynamicznym wzrostem liczby samochodów w Polsce i ukierunkowaniem preferencji na przejazdy własnymi środkami transportu coraz wyraźniej zaznacza się dysproporcja pomiędzy potrzebami a stanem faktycznym ciągów komunikacyjnych (Wilk, Pawlak 2014). W najbardziej zatłoczonych miastach Polski kierowcy i pasażerowie tracą czas, jadąc ze średnią prędkością 10-15 km/h (Piłat 2008).

Olsztyn również znajduje się w grupie miast, w których czas przejazdu wydłuża się przez zatłoczenie. W 2014 r. miasto to oficjalnie zamieszkiwało ${ }^{7} 173831$ osób. W południowo-wschodniej części miasta (osiedla: Generałów, Jaroty, Nagórki i Pieczewo), stanowiącej tzw. sypialnię miejską i połączonej z centrum tylko dwiema ulicami, mieszkało łącznie ponad 55000 osób (Raport o stanie miasta... 2012). Dla porównania, we wszystkich sześciu gminach podmiejskich (obszary wiejskie) zameldowanych było łącznie 51681 osób. W 2014 r. liczba samochodów zarejestrowanych przez mieszkańców miasta sięgnęła poziomu 78621 sztuk (GUS), co pozwoliło obliczyć liczbę osób przypadających średnio na 1 samochód osobowy - 2,21. W tym samym roku liczba samochodów posiadanych przez mieszkańców powiatu olsztyńskiego wyniosła łącznie 60547 (przy liczbie ludności 123049 osób), a wskaźnik 2,03. Za pomocą wskaźników oszacowano ${ }^{8}$ liczbę samochodów posiadanych przez mieszkańców miejskiej „sypialni” i podmiejskich gmin (tabela 1 ).

Z przedstawionych danych wynika, iż zatłoczeniu w szczycie natężenia ruchu potencjalnie wygenerowanemu przez mieszkańców czterech osiedli miejskich próbujących dojechać do centrum dwiema ulicami mogłaby dorównać tylko kongestia wywołana łącznie przez mieszkańców wszystkich sześciu podmiejskich gmin. Można zatem założyć, iż przeprowadzka z mieszkania w bloku na osiedlu Jaroty do domu pod miastem w pewien sposób wręcz odciąża miasto poprzez przesunięcie części ruchu drogowego z niewydolnych arterii miasta na mniej uczęszczane drogi dojazdowe 9 .

\footnotetext{
7 W niniejszym artykule posłużono się danymi GUS o liczbie osób zameldowanych, zdając sobie sprawę, iż liczba ta nie odzwierciedla w pełni liczby osób faktycznie zamieszkujących dany obszar.

8 Posłużono się wartościami szacowanymi, gdyż dla celów niniejszego artykułu istotna była skala wielkości, a nie dokładne liczby.

9 Przywołując opisane w poprzedniej części artykułu wyniki badań ankietowych, można założyć bowiem, iż większość osób wybierze lokalizację pod miastem dobrze skomunikowaną z miejscem pracy, pozwalającą wręcz ominąć konieczność przejazdu przez centrum miasta, np. połowa pracowników UWM mieszkają-
} 
Liczba ludności i liczba samochodów na badanym obszarze w 2014 r.

\begin{tabular}{|l|c|c|}
\hline \multicolumn{1}{|c|}{ Badany obszar } & Liczba ludności & $\begin{array}{c}\text { Liczba samochodów rze- } \\
\text { czywista lub szacowana }\left(^{*}\right)\end{array}$ \\
\hline Olsztyn & 173831 & 78621 \\
\hline Powiat & 123049 & 60547 \\
\hline Osiedla: Generałów, Jaroty, Nagórki i Pieczewo & $55445^{\mathrm{a}}$ & $25100^{*}$ \\
\hline Gminy sąsiednie (wiejskie), w tym: & 51681 & $25430^{*}$ \\
Barczewo (wieś) & 10185 & $5012^{*}$ \\
Dywity & 11097 & $5460^{*}$ \\
Gietrzwałd & 6485 & $3191^{*}$ \\
Jonkowo & 7090 & $3489^{*}$ \\
Purda & 8507 & $4186^{*}$ \\
Stawiguda & 7656 & $376^{*}$ \\
\hline
\end{tabular}

a Dane z roku 2011.

Źródło: opracowanie własne na podstawie danych GUS.

\section{Podsumowanie i wnioski}

Postępujące zjawisko suburbanizacji występuje również w Polsce, zatem budzi szereg obaw odnośnie do prognozowanych konsekwencji oraz pytań związanych z wyborem najkorzystniejszych rozwiązań. Wizja miasta rozlanego, stojąca w opozycji wobec popieranej aktualnie idei smart growth, budzi sprzeciw, a argumenty przeciw suburbanizacji stają się wytycznymi dla władz niektórych miast ${ }^{10}$. Jeżeli zagrożenia mają wymiar uniwersalny, a suburbanizacja zawsze jest „zabójcza” (Kubicki 2014) oraz ma charakter rabunkowy wobec walorów przyrodniczych i społecznych, zatrzymanie procesu przyniesie wyłącznie korzyści. Jednakże, jak podkreśla J.K. Brueckner (2001), jeśli krytyka nie jest w pełni uzasadniona, a hamowanie rozwoju strefy podmiejskiej przyniesie niewiele korzyści, w efekcie końcowym stracą mieszkańcy, gdyż będą „upychani w coraz bardziej zatłoczonych miastach bez ważnego powodu, co obniży ich standard życia”. W niniejszym artykule zasygnalizowano nieoczywistość skutków suburbanizacji. Z poczynionych obserwacji wynika bowiem, iż nie zawsze występuje

cych pod Olsztynem dojeżdża drogą krajową nr 51, której przepustowość pozwala na zwiększony ruch bez wywołania kongestii.

$10 \mathrm{~Np}$. w „Podsumowaniu zgłoszonych uwag do dokumentu projektu Strategii Rozwoju Miasta. Bytom 2020+ wraz z jego oceną oddziaływania na środowisko w ramach konsultacji społecznych” zapisano, iż „Suburbanizacja jest jednym głównych zagrożeń dla rozwoju współczesnych miast i aglomeracji. [...] W Bytomiu istnieje wiele terenów, które zagospodarowane w nieodpowiedni sposób mogą przyczynić się do nasilenia się zjawiska suburbanizacji. Stąd wydaje się, że należy poświęcić jej należytą uwagę w Strategii” (http://www. bytom.pl/rozwoj). 
bezpośrednia zależność pomiędzy napływem ludności na podmiejskie obszary wiejskie a nadmiernymi, nierentownymi inwestycjami infrastrukturalnymi. Przykład gmin podolsztyńskich pokazuje bowiem, iż zabudowa podmiejska może być skoncentrowana przy istniejących ciągach komunikacyjnych, a realizację nowych połączeń lub też inwestycji w infrastrukturę techniczną gmina może odkładać do momentu zagęszczenia zabudowy do odpowiedniej skali. Nowi mieszkańcy nie muszą generować rzeczywistych obciążeń dla budżetu gminy, natomiast często podwyższają wpływy. Ponadto założenie, iż były mieszkaniec miasta jest skazany na zamianę autobusu czy tramwaju na własny samochód, również nie zawsze odzwierciedla rzeczywistość, w której transport indywidualny wybierany jest przede wszystkim dla wygody. Dodatkowo warto podkreślić, iż pod miasto najczęściej przeprowadzają się osoby już posiadające własny samochód i preferujące dojazdy indywidualne, zatem ruch na drogach dojazdowych do miasta nie musi mieć charakteru nowo powstałego, lecz może zostać przesunięty z zatłoczonych ulic wewnątrz miasta na drogi o wyższej przepustowości.

Autorki niniejszego artykułu zdają sobie sprawę, iż obserwacje dotyczą ograniczonego obszaru, więc wnioski nie mogą być uznawane za reprezentatywne dla wszystkich regionów Polski. Jednakże sygnalizują one brak uniwersalności przywołanych argumentów przeciwko suburbanizacji oraz udowadniają niejednoznaczność skutków. W związku z tym władze samorządowe, wybierając konkretne działania z zakresu polityki przestrzennej, powinny rozważyć zarówno wady (które nie zawsze występują), jak i zalety (które mogą zaistnieć). Dzięki obniżeniu kosztów komunikacji z miastem coraz więcej osób może korzystać z dostępności tańszych i większych nieruchomości zlokalizowanych w strefie podmiejskiej. Wygodny dom pod miastem, kiedyś kojarzony z luksusową willą i będący wyłącznie przywilejem elit, jest obecnie w zasięgu finansowym rodzin z tzw. klasy średniej i tym samym stał się korzystną alternatywą dla drogich i ciasnych mieszkań w zatłoczonym mieście. Nadmierne ograniczanie możliwości budowy domów mieszkalnych w strefie podmiejskiej spowoduje eskalację cen nieruchomości i ograniczy tym samym wolność konsumenckiego wyboru. Można zatem wywnioskować, iż suburbanizacji nie należy wyłącznie zatrzymywać, trzeba natomiast ją ukierunkować, bowiem obszary podmiejskie to także obszary cenne przyrodniczo i kulturowo, które powinny być bezwzględnie chronione. Wymaga to rzetelnego, wizjonerskiego planowania przestrzennego, tworzonego przez osoby otwarte na wszystkie wymiary suburbanizacji. Rozbudowa podmiejskich miejscowości i napływ nowych mieszkańców to bowiem nie tylko potencjalne koszty, ale także ożywianie i odmładzanie „wymierających” wsi, zwiększanie środków finansowych w budżecie gminy oraz poprawa warunków mieszkaniowych byłych mieszkańców zatłoczonych miast.

\section{Bibliografia}

Bagiński E., 2011, Suburbanizacja - nieunikniona przyszłość osadnictwa?, „Studia Miejskie” nr 3.

Bento A.M., Franco S.F., Kaffine D., 2011, Is there a double-dividend from anti-sprawl policies?, "Journal of Environmental Economics and Management" No. 61. 
Brueckner J.K., 2001, Urban sprawl: Lessons from urban economics, "Brookings-Wharton Papers on Urban Affairs".

Brueckner J.K., Helsey R.W., 2011, Sprawl and blight, "Journal of Urban Economics” No. 69.

Brueckner J.K., Largey A.G., 2008, Social interaction and urban sprawl, "Journal of Urban Economics" No. 64(1).

Bruegmann R., 2005, Sprawl: A compact history. University of Chicago Press, Chicago.

Bruegmann R., 2006, How sprawl got a bad name, "The American Enterprise" June.

Burchfield M., Overman H.G., Puga D., Turner M.A., 2006, Causes of sprawl: a portrait from space, "Quarterly Journal of Economics" No. 121.

Charmes E., 2009, On the residential 'clubbisation' of French periurban municipalities, "Urban Studies" No. 46(1).

Cellmer R., 2012, Spatial analysis of local real estate market activity - the example of the city of Olsztyn, "Studia i Materiały Towarzystwa Naukowego Nieruchomości".

Cheshire P., Sheppard S., 2002, The welfare economics of land use planning, "Journal of Urban Economics" No. 52(2).

Coisnon T., Oueslati W., Salanie J., 2013, Urban sprawl occurrence under spatially varying agricultural amenities, "Regional Science and Urban Economics" No. 01.

Fisher E.M., 1942, Aspects of zoning, blighted areas, and rehabilitation laws, "American Economic Review" No. 32.

Glaeser E.L., Kahn M., 2003, Sprawl and urban growth, National Bureau of Economic Research, Cambridge. NBER Working Paper Series No. 9733.

Glaeser E.L., Kohlhase J.E., 2003, Cities, regions and the decline of transport costs, "Harvard Institute of Economic Research Discussion Paper” No. 2014.

Heffner K., 2011, Semiurbanizacja a suburbanizacja. Ewolucja procesów w aglomeracji opolskiej, „Studia Miejskie" nr 3.

Irwin E., Bockstael N., 2007, The evolution of urban sprawl: evidence of spatial heterogeneity and increasing land fragmentation, "Proceedings of the National Academy of Sciences" No. 104(52).

Kajdanek K., 2012, Suburbanizacja po polsku, Nomos, Kraków.

Kowalewski A., Mordasewicz J., Osiatyński J., Regulski J., Stępień J., Śleszyński P., 2014, Ekonomiczne straty $i$ społeczne koszty niekontrolowanej urbanizacji w Polsce - wybrane fragmenty raportu, „Samorząd Terytorialny" nr 4.

Kubicki P., 2014, Zabójcza suburbanizacja. Społeczne i kulturowe skutki suburbanizacji [wykład wygłoszony na konferencji „Powrót do miasta” 10.10.2014 w olsztyńskim Parku Naukowo-Technologicznym].

Longley P.A., Goodchild M.F., Maguire D.J., Rhind D.W., 2006, GIS. Teoria i praktyka, przeł. M. Lenartowicz et al., Wydawnictwo Naukowe PWN, Warszawa.

Margo R., 1992, Explaining the postwar suburbanization of population in the United States: The role of income, "Journal of Urban Economics" No. 31(2).

Mieszkowski P., Mills E., 1993, The causes of metropolitan suburbanization, "Journal of Economic Perspectives" No. 7(3).

Nechyba T.J., Walsh R.P., 2004, Urban sprawl, "Journal of Economic Perspectives" No. 18(4).

Nelson A.C., Burby R.J., Feser E., Dawkins C.J., Malizia E.E., Quercia R., 2004, Urban containment and central-city revitalization, "Journal of the American Planning Association" No. 70.

Paszkowski Z., 2014, Tendencje w rozwoju polskiej urbanizacji, [w:] Przestrzeń życia Polaków, oprac. J. Sepioł, Stowarzyszenie Architektów Polskich SARP, Warszawa.

Pieniążek M., Rogalińska D., 2015, Suburbanizacja jako wyzwanie badawcze dla statystyki regionalnej, „Studia i Materiały. Miscellanea Oeconomicae" t. 1, nr 4.

Piłat B., 2008, Kierowcy sami korkują Kraków, „Gazeta Wyborcza” z 5 września.

Plan Rozwoju Lokalnego Gminy Dywity. W-MARR, Olsztyn 2004.

Plan zrównoważonego rozwoju publicznego transportu zbiorowego dla miasta Olsztyna na lata 2012-2027, Public transport consulting, Reda-Olsztyn 2012.

Plantinga A., Bernell S., 2007, The association between urban sprawl and obesity: is it a two-way street, "Journal of Regional Science" No. 47(5). 
Problem suburbanizacji, 2005, red. P. Lorens, Urbanista, Warszawa.

Radziewicz C., Grzelec K., Karolak A., Wolański M., 2013, Raport o stanie komunikacji miejskiej w Polsce w latach 2000-2012, Izba Gospodarcza Komunikacji Miejskiej, Warszawa.

Raport o stanie miasta Olsztyn za lata 2010, 2011, 2012, Instytut Badań i Analiz, Grupa OSB Olsztyńska Szkoła Biznesu, Olsztyn.

Richardson H.W., Gordon P., 2001, Compactness or sprawl: America's future vs. the present, [w:] Cities for the New Millenium, eds. M. Echenique, A. Saint, SPON Press, London.

Szydłowski G., 2016, Stawiguda i Dywity będq miały swoją komunikację, http://olsztyn.wyborcza.pl/ olsztyn/1,48726,20692892,mala-rewolucja-dwie-gminy-beda-mialy-swoja-komunikacje.html\#BoxLok OlszLink (dostęp 15 września 2016).

Trojanek M., 2009, Preferencje nabywców na pierwotnym rynku mieszkaniowym w Poznaniu, „Acta Scientiarum Polonorum. Administratio Locorum" nr 8(1).

Wappa P., Halicka K., 2011, Znaczenie i źródło kongestii transportowej na przykładzie białostockiej aglomeracji miejskiej, „Economy and Management” nr 4.

Wilk T., Pawlak P., 2014, Kongestia transportowa, „Logistyka” nr 6.

Wolny A., 2016, Accessibility of real estate by transportation as a determinant of the development of suburban real estate markets - case study, "Real Estate Management and Valuation" vol. 24, Is. 1.

Wu J., 2006, Environmental amenities, urban sprawl and community characteristics, "Journal of Environmental Economics and Management" No. 52(2).

Zborowski A., Raźniak P., 2013, Suburbanizacja rezydencjonalna w Polsce-ocena procesu, „Studia Miejskie” nr 9.

Źróbek S., Trojanek M., Źróbek-Sokolnik A., Trojanek R., 2015, The influence of environmental factors on property buyers' choice of residential location in Poland, "Journal of International Studies" vol. 7, No. 3.

Źróbek-Różańska A., Zadworny D., 2016, Can urban sprawl lead to urban people governing rural areas? Evidence from the Dywity Commune, Poland, "Cities. International Journal of Urban Policy and Planning" vol. 59.

Źróbek-Różańska A., Zysk E., 2015, Czy rozlewajace się miasto odmładza podmiejską wieś? Studium podolsztyńskich gmin wiejskich, „Wieś i Rolnictwo” nr 4(169).

Źróbek-Różańska A., Zysk E., Źróbek-Sokolnik A., 2016, Studies over characteristics shaping residential attractiveness of suburban rural areas, "Acta Scientiarum Polonorum: Oeconomia” No. 15(3).

http://dywity.e-mapa.net (dostęp 25 sierpnia 2016).

http://www.bytom.pl/rozwoj (dostęp 15 września 2016).

http://www.portalsamorzadowy.pl/prawo-i-finanse/planowanie-przestrzenne-gminy-maja-gigantyczne-zobowiazania-finansowe,74766.html (dostęp 14 września 2016). 